\title{
MORE PROTECTION FOR VICTIMS OF DOMESTIC VIOLENCE? \\ (THE DOMESTIC VIOLENCE, CRIME AND VICTIMS ACT 2004)
}

\author{
Susan Edwards*
}

\section{INTRODUCTION}

In 2004, the government introduced the Domestic Violence, Crime and Victims Act (DVCVA). Baroness Scotland, in opening the Bill's second reading in the House of Lords, said: "The Bill represents the most radical overhaul of domestic violence legislation in 30 years. It reflects the fact that domestic violence is unacceptable, that victims must be protected and offenders punished." 1

In broad terms, protection for victims is provided by introducing amendments to existing civil and criminal offences including extending police powers in making, both common assault and a breach of a non-molestation order, arrestable offences (section 10 and section 1); offering protection to a wider range of persons by including same-sex couples in the meaning of "cohabitants" (by amending Part 4 Family Law Act (FLA) 1996); including in the definition of "associated persons" same-sex couples (by amending Part 4 FLA), and perhaps of the greatest significance creating an entirely new homicide offence of "causing or allowing the death of a child or vulnerable adult" (section 5). There are several provisions intended to empower victims of domestic violence by allowing them a greater participation in the justice process, including the right to make representation in court (sections 35-46) and by providing additional support in the form of a Victim's Code, although the remit of this code of practice is still yet to be determined (section 32). Finally, there is also a provision, which establishes independent investigations of domestic homicides termed "domestic homicide reviews" (section 9). This commentary considers to what extent the new legislation will assist in the protection of victims of domestic violence.

\footnotetext{
* BA (CNAA), MA, PhD (Manc), LLM (Reading), Deputy Dean of Law, Professor of Law, University of Buckingham; Barrister, (Door Tenant) Clarendon Chambers, 1 Plowden Buildings, Temple, London EC4Y 9BU.

${ }^{1}$ Hansard, HL, col 949, December 15, 2003.
} 


\section{THE DENNING LAW JOURNAL}

\section{BACKGROUND AND CONTEXT}

The Act is a demonstration of the government's wider commitment to provide enhanced protection for victims of domestic violence. Domestic violence homicide of adult partners continues to account for approximately 130 victims each year since $1997^{2}$ (whilst over the last three decades the number has been on average 110 victims each year). Domestic violence homicide remains largely a gender based crime. Of all adult female victims of homicide over the last decade (1995-2005) between 40-45 per cent were killed by current male partners or ex-partners. ${ }^{3}$ It is widely accepted that intervening at the earliest stage in this escalating chain of violence can have a significant impact in the prevention of domestic homicide. The rise in both recorded incidents and prosecutions for domestic assault reflects the increased commitment of police and prosecutors to record and prosecute in these cases. A total of 35,231 prosecutions were recorded for the final eight months (April to December) of 2005. ${ }^{4}$ For the Metropolitan Police District alone, the number of cases rose from 2,030 in 2004 to 3,272 in $2005 .^{5}$ (It is worth noting, by way of comparison, that in 1985 as few as 384 cases of domestic violence were recorded by police). ${ }^{6}$ This increase in prosecutions has been aided by establishing specialist courts to hear these cases $^{7}$ and by the collection and use of enhanced evidence gathering, including photographic evidence and witness statements. As part of this commitment, the Crown Prosecution Service is also considering whether expert witnesses ${ }^{8}$ might be of assistance in supporting prosecution cases where the complainant is hostile to the proceedings and whose witness statement controverts any testimony given in oral evidence.

\footnotetext{
${ }^{2}$ K Coleman, C Hird and D Povey, Violent Crime Overview, Homicide and Gun Crime 2004/2005 (Supplementary Volume to Crime in England and Wales 2004/2005) (London: Home Office, January 26, 2006) Table 2.05 p. 58. Although it is to be noted that the Home Office Bulletin noted above records that domestic violence homicide as a proportion of all homicide has fallen, this is potentially misleading, since what has actually occurred is that an increase in homicides committed by strangers has merely impacted on the proportion of homicides that arise from domestic violence.

${ }^{3}$ See note 2 above p.50.

${ }^{4}$ The Independent, March 9, 2006.

${ }^{5}$ The Evening Standard, March 8, 2006.

${ }^{6}$ See The Times, October 6, 1986. See also S. Edwards, Policing Domestic Violence (London: Sage, 1989).

${ }^{7}$ M Hester, and N Westmarland, Tackling Domestic Violence: effective interventions and approaches, Home Office Research Study 290 (London: Home Office, 2005).

${ }^{8}$ M. M. Dempsey The Use of Expert Witness Testimony in the Prosecution of Domestic Violence (London: Crown Prosecution Service, 2004). This document summarises a report drafted by Professor S Edwards (The Law School, University of Buckingham) regarding the use of expert witness testimony in the prosecution of domestic violence.
} 


\section{THE DENNING LAW JOURNAL}

\section{SENTENCING}

In addition, the sentencing practice of the courts in cases of domestic homicide and domestic assault demonstrates that sentencers are treating such offences more seriously than was the case in earlier years. In December 2002, the Attorney General, referred three cases of domestic violence homicide to the Court of Appeal with a view to encouraging judges to impose stiffer terms of imprisonment than had hitherto been the case. In Suraton, Humes and Wilkinson [2002], ${ }^{9}$ whilst the Court of Appeal agreed that mere loss of temper or jealous rage is not sufficient to establish loss of self control, nevertheless it found that Suraton's three and a half year sentence and Wilkinson's four year sentence were not "unduly lenient", and Humes seven-year sentence was not considered "lenient” [sic]. In Suraton, Lord Justice Mantell stated:

"Even if it would ever be sensible to attempt to lay down guidelines in this notoriously difficult area, we quite agree that it would be inappropriate for the Court [of Appeal] as presently constituted to do so or for any Court to do so without the Sentencing Advisory Panel having first been involved.”

The Sentencing Advisory Panel commenting on this case said:

“...the court did not disagree with the proposition that in cases of manslaughter committed after provocation arising out of possessiveness, jealousy or unfaithfulness, the ordinary sentencing range lies between 5 and 7 years imprisonment."10

The Criminal Justice Act (CJA) of 2003 placed on a statutory basis the Sentencing Guidelines Council (SGC) whose role is to provide authoritative guidance on sentencing in criminal offences. By 2005, the SGC issued guidance on sentencing in manslaughter cases by reason of provocation, providing for three sentencing ranges depending on the degree of provocation. The first range has a starting point of three years imprisonment where the degree of provocation is high, the second range starts at eight years where there is a substantial degree of provocation over a short time and the third range starts at twelve years where there is a low degree of provocation. ${ }^{11}$ The CJA

\footnotetext{
${ }^{9}$ Attorney General's References (Nos 74, 95 and 118 of 2002) [2003] Crim LR, 414.

${ }^{10}$ Sentencing Advisory Panel Manslaughter By Reason Of Provocation The Panel's Advice To The Sentencing Guidelines Council (London: May 2005) p. 8.

${ }^{11}$ Manslaughter by Reason of Provocation Sentencing Guidelines Council, $28^{\text {th }}$ November 2005. Issued a definitive guideline in accordance with section 170(9) of the
} 


\section{THE DENNING LAW JOURNAL}

2003 also provides for longer sentences in all cases involving violence not resulting in death. ${ }^{12}$ By 2004, the Court of Appeal in $R v$ Madar, ${ }^{13}$ a case of domestic assault, upheld a sentence of four years imprisonment for repeated acts of serious "domestic" violence. ${ }^{14}$

With regard to the civil law, where there have been breaches of nonmolestation orders, the courts have also started to impose longer sentences. Although in Loughran $v$ Pandya, ${ }^{15}$ the court reduced a two year sentence suspended for two years to that of eight months imprisonment suspended for two years.

\section{THE LIMITATIONS OF THE DVCVA}

Even with the advent of the DVCVA some issues relating to domestic violence have still been left unaddressed. For example, there is no definition of domestic violence provided in the Act. Lord Thomas of Gresford commented on this omission at the Bill stage:

"It is curious to have it called Domestic Violence, Crime and Victims Bill, without anyone having a clear idea how far domestic violence extends; who may be parties to domestic violence; who may not be; what type of conduct is regarded as domestic violence and whether it covers psychological harm." 16

The definition of domestic violence which is widely used is found in the Home Office in Domestic violence: a national report, ${ }^{17}$ which reads: "Any

Criminal Justice Act 2003. Although it is to be noted that the SGC did not include previous acts of domestic violence by the defendant against the deceased as an aggravating factor. On this point it may be considered to be incongruent with both the approach of the Criminal Justice Act 2003 to violence in general and the Sentencing Guidelines Council Consultation Document on Domestic Violence 2006, where a history of violence is an aggravating factor.

${ }^{12}$ See sections 227, 228 and 229 Criminal Justice Act 2003.

${ }^{13}$ Court of Appeal, Criminal Division [2004] All ER (D) 91 (Sep); [2004] EWCA Crim 1524.

${ }^{14}$ Criminal Justice Act 2003, section 327 "relevant sexual or violent offence" includes offences where a sentence of imprisonment of 12 months and above is imposed, relevant violent offence includes section 18 Offences Against the Person Act 1861.

${ }^{15}$ Court of Appeal, Civil Division [2005] EWCA Civ 1720, (Transcript: Smith Bernal).

${ }^{16}$ Hansard, HL, col 1218, March 9, 2004. See also House of Commons Research Papers: Research Paper 04/44 2004 The Domestic Violence, Crime and Victims Bill [HL]: Domestic violence provisions June 9, 2004.

${ }^{17}$ Domestic violence: a national report (London: Home Office, March 2005). 


\section{THE DENNING LAW JOURNAL}

incident of threatening behaviour, violence or abuse (psychological, physical, sexual, financial or emotional) between adults who are or have been intimate partners or family members, regardless of gender or sexuality." ${ }^{18}$ The Act also fails to offer all victims equal protection since the degree of protection is affected by legal differences in the relationship of the parties concerned. ${ }^{19} \mathrm{~A}$ distinction is made between the duration of an occupation order made in favour of a spouse and an order made in favour of a cohabitant. ${ }^{20}$

Further, whilst it was the aspiration of many that the civil and criminal law justice systems and their responses to domestic violence would move towards being more integrated, the criminal courts are still not obliged to address what civil orders may be in process or even make enquiries about, for example, child contact or housing issues or to consider the views of the victim who will not be party to the proceedings. Thorpe LJ, had anticipated that the Act would better integrate the civil and criminal responses. In Lomas and Parle $(2004)^{21}$ he said:

“[47] However effectively the proceedings are managed a perpetrator may face sentence for the same act which amounts to both a breach of an injunction made in family proceedings and also a crime under the 1997 Act. Of course the sentencing courts do not share the same objective and operate in different ranges. The judge in family proceedings has to fit a custodial sentence within a range of zero to 24 months. An important objective for him is to uphold the authority of the court by demonstrating that its orders cannot be flouted with impunity. Nevertheless there will be a shared deterrent objective in the punishment of domestic violence by imprisonment. [48] Clearly therefore the first court to sentence must not anticipate or allow for a likely future sentence. It is for the second court

${ }^{18}$ ibid para 10, p 7. The CPS definition is drafted in almost identical terms, "any criminal offence arising out of physical, sexual, psychological, emotional or financial abuse by one person against a current or former partner in a close relationship, or against a current or former family member" Domestic Violence How Prosecution Decisions are Reached (London: Crown Prosecution Service 2005) and the Sentencing Guidelines Council guideline Manslaughter by reason of provocation defines domestic violence as "any incident of threatening behaviour, violence, or abuse [psychological, physical, sexual, financial or emotional] between adults who are or have been intimate partners, regardless of gender or sexuality."

${ }^{19}$ C Bessant The Domestic Violence, Crime and Victims Act 2004 : A Guide (London: The Law Society 2005) p 4.

${ }^{20}$ ibid above p 5.

${ }^{21}$ [2004] 1 WLR 1643. 


\section{THE DENNING LAW JOURNAL}

to sentence to reflect the prior sentence in its judgment in order to ensure that the defendant is not twice punished for the same act. It is essential that the second court should be fully informed of the factors and circumstances reflected in the first sentence. The defendant is often publicly funded to defend the proceedings in each court and may well have different solicitors and counsel in each justice system. There is therefore an obligation on the first court to ensure that the basis of its sentence is fully expressed and that a transcript of its judgment is made available to the second court, as Judge Harris directed in the present case. [49] Experience suggests that proceedings in the criminal justice system are likely to require more extensive preparation and to prove more protracted than committal proceedings in the family justice system. Therefore the application to commit should be issued promptly after the alleged breach and listed without delay. That discipline will ensure that, if proved, the contempt will have been punished before any sentence in parallel criminal proceedings." 22

\section{EXTENDING CIVIL AND CRIMINAL PROTECTION}

Following Safety and Justice: the governments proposals on Domestic Violence, ${ }^{23}$ sections 2,3, and 4, of the DVCVA extends Part 4 of the FLA to non-cohabiting couples in a relationship. The meaning of "cohabitants" now include parties in same-sex relationships. In defining non-cohabiting relationships which fall within the Act, section 4 amends section 62(3) of the FLA (associated persons) adding sub section (ea) which requires the parties to be or have been in "...an intimate personal relationship with each other which is or was of significant duration." How the courts will interpret "intimate," "personal" and "of significant duration" is yet to be determined. Some guidance is offered in the explanatory notes to the Bill which suggests that relationships need not be sexual but should be "intimate and personal." One commentator at least is of the opinion that platonic friendships, and short, very intense relationships, will be excluded. ${ }^{24}$ Certainly, each case will need to be decided on its own particular facts and the courts should aim to reflect the contemporary reality of the diversity of intimate and personal encounters.

Under the DVCVA common assault is now an arrestable offence. Section 10(1) of the Act amends the Police and Criminal Evidence Act 1984 Schedule

\footnotetext{
${ }^{22}$ ibid paras 47- 49.

${ }^{23}$ Home Office, July 2003, para 38-50.

${ }^{24}$ Bessant note 19 above.
} 


\section{THE DENNING LAW JOURNAL}

1A, which now allows police to arrest in cases of common assault (the least serious of criminal assault offences), without obtaining a warrant, so that immediate protection for victims of domestic violence can be ensured. ${ }^{25}$ In 1984, Sherman and Berk, ${ }^{26}$ in a research experiment where police were randomly assigned one of a number of responses (arrest, mediation, and removal from the scene) in minor domestic violence incidents, and then followed up these individual cases to assess the deterrent effect of the assigned response, concluded that "arrest is best" in deterring subsequent domestic incidents. The research was replicated in many American cities and a pro-arrest policy was considered to impact significantly on reducing repeat incidents of domestic violence. However, the Sherman and Berk experiments were also criticised for too readily concluding that the pro-arrest police response was the determining variable in deterring domestic violence repeat incidents. Critics were concerned that the decline in repeat incidents of domestic violence which characterised cases where the police response was one of arresting the suspect was an indicator not of a real decline in repeat violence but instead the consequence of victims simply not calling police on subsequent occasions. Despite this caveat, it is now widely accepted that, in the long-term endeavour of reducing domestic violence, police pro-arrest policies not only serve to remove the violent perpetrator but also convey an important symbolic message to individual perpetrators and to society that domestic violence is unacceptable.

The implementation of a positive arrest policy in the DVCVA is reinforced by being included in the Policing Performance Assessment Framework ${ }^{27}$ whereby police performance is measured by the percentage of cases where police make an arrest where they have the power to do so. Police forces in the UK have been considering how they will implement the new arrest provision. The Metropolitan police in London have stated: "The Met is committed to holding domestic violence offenders accountable and we will arrest given reasonable grounds." ${ }^{28}$ Staffordshire Police have stated:

"The onus will be on officers to make arrests where evidence of abuse is found and the power of arrest exists ...from March 12005 Staffordshire Police have been completing a detailed $\log$ in all domestic violence cases to which they are called. The log, known as DIAL (Domestic Investigation Arrest Log or, if there is no crime, Domestic Intelligence Assessment Log), will

\footnotetext{
25 July 1, 2005 SI No.2005/1705.

26 L.W. Sherman. and R.A. Berk, "The Specific Deterrent Effects of Arrest for Domestic Assault” (1984) American Sociological Review 49 (2): 261-72.

${ }^{27}$ http://police.homeoffice.gov.uk/performance-and-measurement/performanceassessment/assessments-2004-2005/

${ }^{28}$ http://www.met.police.uk/dv/
} 


\section{THE DENNING LAW JOURNAL}

include evidence and intelligence-gathering checklists. These will encourage officers to carry out tasks including photographing the victim or scene and seizing evidence such as mobile phones containing threatening text messages. The log will include victim and witness statements, removing the need for separate paperwork, and will give officers the chance to make an early risk assessment of an incident and a tailored safety plan for the victim."29

However, it must be remembered that an arrest provision does not compel officers to arrest and whether police exercise their arrest power is a matter left to an individual officer's discretion and what s/he consider reasonable grounds.

Other protective measures in the DVCVA include the expansion in the use of a restraining order. Previously, restraining orders were only provided for under the Protection from Harassment Act 1997 (PFHA) section 5. This remedy is now part of the DVCVA (section 12(1)). Perhaps the most contentious aspect of this remedy is that such orders may be imposed even in cases where a person is acquitted of an offence. Section 12(5) inserts a new section 5A in the PFHA which provides: "(1) A court before which a person ('the defendant') is acquitted of an offence may, if it considers it necessary to do so to protect a person from harassment by the defendant, make an order prohibiting the defendant from doing anything described in the order." In the House of Lords debate on the Bill it was stated: "The government recognises that the amendment is wide, but believes it necessary to deal with those cases where there has been clear evidence during the proceedings that the victim needs protection, but insufficient evidence to convict., ${ }^{30}$

The DVCVA (section 1) also makes a breach of a non-molestation order a criminal offence, carrying a maximum five-year prison sentence, thus addressing the ineffectiveness of the enforcement of civil provisions. In 2004, ${ }^{31}$ 20,890 non-molestation orders with a power of arrest were granted. Breaches of non-molestation orders were not taken seriously by the police or by the courts, few individuals were proceeded against for such breaches and sentences handed down by the courts were nominal. ${ }^{32}$ Whilst section 47 (2) b of the FLA, required a power of arrest to be attached to non-molestation orders, "unless satisfied that in all the circumstances of the case the applicant or child will be

\footnotetext{
${ }^{29}$ http://www.staffordshire.police.uk/news/2005/02_feb/news528.htm

${ }^{30}$ Hansard (HL) col GC, February 2, 2004.

${ }^{31}$ Judicial Statistics 2004 (London: Department of Constitutional Affairs 2005) Cm 6565, Table 5.10.

${ }^{32}$ See Odumosu v Aiyeola (Court of Appeal) October 16, 1996; A-A v B-B [2001] 2FLR 1; Lomas v Parle [2004] 1 WLR 1643; Aquilina v Acquilina [2004] EWCA Civ 504; Bartley (t/a Lundy) v Wilson [2004] EWCA Civ 1338.
} 


\title{
THE DENNING LAW JOURNAL
}

adequately protected without such a power of arrest" the enforcement mechanism where orders were breached still remained ineffective. In Robinson $v$ Murray (2006), ${ }^{33}$ the judge found that the defendant was guilty of three breaches of a non-molestation order, and sentenced him to eight months' imprisonment in respect of each breach, to be served concurrently. The defendant appealed contending that the sentence was manifestly excessive in the circumstances. The application was dismissed.

\section{A NEW KIND OF HOMICIDE}

The DVCVA introduces a new offence in section 5(1) of "causing or allowing the death of a child or vulnerable person" where that person is a member of the same household, (household member being widely drafted). Section 5 (1) provides:

\begin{abstract}
“A person ('D') is guilty of an offence if - (a)a child or vulnerable adult (' $\mathrm{V}$ ') dies as a result of the unlawful act of a person who- (i)was a member of the same household as $V$, and (ii) had frequent contact with him,(b)D was such a person at the time of that act, (c)at that time there was a significant risk of serious physical harm being caused to $\mathrm{V}$ by the unlawful act of such a person, and (d) either D was the person whose act caused V's death or - (i)D was, or ought to have been, aware of the risk mentioned in paragraph (c),(ii) D failed to take such steps as he could reasonably have been expected to take to protect $\mathrm{V}$ from the risk, and (iii) the act occurred in circumstances of the kind that $\mathrm{D}$ foresaw or ought to have foreseen. (2)The prosecution does not have to prove whether it is the first alternative in subsection (1)(d) or the second (subparagraphs (i) to (iii)) that applies." ${ }^{34}$
\end{abstract}

These inelegantly drafted paragraphs $\mathrm{d}(\mathrm{i})$ to (iii) are to be read conjunctively. The Home Office Circular, ${ }^{35}$ in its description of the offence, is somewhat clearer:

"The offence provides that members of a household who have frequent contact with a child or vulnerable adult will be guilty

\footnotetext{
${ }^{33}$ [2006] 1 FLR 365.

${ }^{34}$ Sections 5 to 8 in force March 21, 2005, SI 2005/579.

${ }^{35}$ Home Office Circular 9/2005 The Domestic Violence and Victims Act 2004:The new Offence of causing the death of a child or vulnerable adult, 04/03/2005, (London: Home Office 2005).
} 


\section{THE DENNING LAW JOURNAL}

if they caused the death of that child or vulnerable adult or three conditions are met: they were aware or ought to have been aware that the victim was at significant risk of serious physical harm from a member of the household; and they failed to take reasonable steps to prevent that person coming to harm; and the person subsequently died from the unlawful act of a member of the household in circumstances that the defendant foresaw or ought to have foreseen.”

The person must be a member of the same household as the child. Although this is to be interpreted loosely and does not require the party to live in the same household, it does, however, require the party to be a regular visitor, so as to include boyfriends who may not cohabit but visit on a regular basis. This provision is designed to address the difficulty which has presented the prosecution for some time exemplified in $R v$ Lane and Another (1985), ${ }^{36}$ where the Court of Appeal held that where it could not be established which of two defendants (in this case a mother and stepfather) were responsible for the death of a 22-month-old baby, then the convictions for manslaughter should be quashed. James and Linda Lane were found guilty of manslaughter at Cardiff Crown Court after their daughter died from a single blow to the skull. The prosecution conceded that the evidence did not establish which of the appellants had inflicted the injuries but invited the jury to draw the inference that both were jointly responsible. At the end of the prosecution case the defence made an application of "no case to answer." The judge rejected the defence submission stating that he was satisfied that there was sufficient prima facie evidence on which the jury could conclude that both had been responsible for the death of the child. As a result the jury convicted. On appeal, the convictions for manslaughter were quashed on the basis that the trial judge ought to have ruled in favour of the appellants on their submission of "no case to answer" because it could not be established which of the two defendants caused the fatal injuries “...import[ing] into the law relating to proof of manslaughter a new test - converting the general responsibility for custody and care into actual presence at the time the blow was struck, even though on the acknowledged facts there were substantial periods when only one of the appellants was present” (see also $R v$ Aston and Another (1991)). ${ }^{37}$ Where both parties made explicit denials, this difficulty in establishing criminal liability for one of the two parties persisted. Although in $R v$ Russell and Another (1987), ${ }^{38}$ where the appellants $\mathrm{A}$ and $\mathrm{M}$ were registered drug addicts, in receipt of daily prescriptions of methadone, which they obtained in liquid form and made

\footnotetext{
${ }^{36}$ [1985] 82 Cr App Rep 5.

37 [1991] Crim LR 701.

38 [1987] Crim LR 494.
} 


\section{THE DENNING LAW JOURNAL}

admissions that "on occasion" they had dipped the child's dummy into the liquid methadone to placate her while she was teething, a conviction for manslaughter followed.

In cases where both parties deny the offence and make no inculpatory statements the judge must direct "no case to answer" on manslaughter or murder if the prosecution cannot establish that there is a case to answer against either defendant. Lord Lane CJ in Galbraith (1981) ${ }^{39}$ said:

"(1) If there is no evidence that the crime alleged has been committed by the defendant, there is no difficulty. The judge will of course stop the case. (2) The difficulty arises where there is some evidence but it is of a tenuous character, for example because of inherent weakness or vagueness or because it is inconsistent with other evidence. (a) Where the judge comes to the conclusion that the prosecution evidence, taken at its highest, is such that a jury properly directed could not properly convict upon it, it is his duty, upon a submission being made, to stop the case. (b) Where however the prosecution evidence is such that its strength or weakness depends on the view to be taken of a witness's reliability, or other matters which are generally speaking within the province of the jury and where on one possible view of the facts there is evidence upon which a jury could properly come to the conclusion that the defendant is guilty, then the judge should allow the matter to be tried by the jury...” 40

In 2003, the Law Commission issued a consultation document followed by a report outlining their concern that co-accused's could and did evade conviction in such circumstances. ${ }^{41}$ Whilst the new provision in the DVCVA addresses this problem in the legislation, there is a concern that the provision may in fact be too broad. The "ought to have foreseen the risk" element embodies an objective test, which is contrary to the test for criminal liability in recklessness, ${ }^{42}$ which following $R v G^{43}$ is subjective. (However two of their

\footnotetext{
${ }^{39}$ [1981] 1 WLR 1039 at p.1042B-D.

${ }^{40}$ See also Bellman [1989] AC 836 at p. 849A, S [1996] Crim LR 346.

${ }^{41}$ Law Commission, Children: Their Non-accidental Death or Serious Injury (Criminal trials) A Consultative Report, Law Com No 279, April 2003; Law Com Report No 282. The full report is available on the internet at www.lawcom.gov.uk.

${ }^{42}$ Recklessness following Metropolitan Police Commissioner v Caldwell [1982] AC 341, established broadly that for offences relating to personal injury the test was a subjective one, ie, “did the D foresee?” whilst for offences against property, for
} 


\section{THE DENNING LAW JOURNAL}

Lordships in $G$, notably, Lord Bingham and Lord Rodger, considered it possible that recklessness could have different meanings in relation to different offences). The objective standard of "ought to have foreseen" in the DVCVA is also found in Osman ${ }^{44}$ where the ambit of art 2 of the European Convention on Human Rights - right to life - is articulated with regard to public authority liability, making public authorities liable for failure to protect an individual's "right to life" if "they knew of a risk to an individual or ought to have known", that such a risk existed. The formulation of an objective test which is a higher standard than a subjective test is clearly driven by the difficulties presenting the prosecution in cases where two parties blame each other for the death of a child or where both simply deny that they did it.

The DVCVA places a duty on the household member to protect the child or vulnerable person in line with the direction of the trial judge to the jury in Lane (cited above) where the judge deemed responsible those who have care and custody of the child, although at the time this direction was held by the Court of Appeal to be a misdirection. An offence under section 5 neither seems to sit with the general principles on recklessness or gross negligence. The burden of proof is on the prosecution (section 5(1)(d)(ii)(a)), to prove that D failed to take steps as he could reasonably have been expected to take to protect the victim. Bessant, for example, points out that in assessment of the element "foresaw or ought to have foreseen" the government do not envisage that a member of the household who could not have reasonably foreseen the risk would be caught by this offence. As Baronness Scotland observed: "For example, it may be that an elderly grandmother in the household was too confused to recognise and act on any sign of risk..."45 The Home Office Circular $^{46}$ states:

“...Depending on the facts of the particular case the court may find that the defendant may have been too frightened to take some of the steps which in other circumstances might have been available to them...there may be limited steps which they could reasonably have taken in order to protect themselves, and even more limited steps which it would be reasonable for

\footnotetext{
example, criminal damage, the test was an objective one ie, "would a reasonable person have foreseen?" It would appear that the test now is subjective.

${ }^{43} R$ v G and another, HL [2003] 4 All ER 765, has overruled Caldwell and re-asserted a subjective test requiring awareness of risk for offences of criminal damage.

${ }^{44}$ Osman v UK (Case 87/1997/871/1083), ECHR [1999] 1 FLR 193.

${ }^{45}$ Hansard, HL, col 1158, March 9, 2004, Baroness Scotland.

${ }^{46}$ Home Office Circular 9/2005 The Domestic Violence and Victims Act 2004: The new Offence of causing the death of a child or vulnerable adult, 04/03/2005, Home Office.
} 


\section{THE DENNING LAW JOURNAL}

them to take to protect the child or vulnerable person who was at risk from violence... this offence is premised on a duty to protect the vulnerable person from harm. All members of the household who had frequent contact with the victim would have that duty. The fact that the defendant may be young..., feel intimidated or have suffered violence, will not in itself be conclusive evidence that it was reasonable for the defendant not to take any steps to protect the victim." 47

It is important that prosecuting authorities and the courts recognise that in cases where children are abused female partners are also frequently assaulted by the perpetrator. Many mothers and female carers who are responsible for the care of children and who experience violence or the threat of violence may be unable to take "reasonable steps" or else to recognise the risks to the child because of their own fear and inability to act. The US case, People $v$ Steinberg $(1989)^{48}$, involving the death of Lisa Nussbaum the adopted daughter of Hedda Nussbaum, and the UK case $R v$ Emery and Hedman (1972), involving the death of (Chanel Hedman) the daughter of Sally Emery and Brian Hedman, provide two clear examples where women who were battered and terrorised by the perpetrator were unable to act to prevent the deaths of children in their care. In the US case, ${ }^{49}$ Lisa Nussbaum died of injuries to her head and body inflicted by Joel Steinberg, (Hedda Nussbaum's cohabitant). Hedda Nussbaum herself sustained a wide range of chronic injuries over time, including a broken nose and gangrenous wounds including a ruptured spleen. In giving evidence for the prosecution she said she ate when permitted to do so, went to the bathroom when permitted to do so, and when asked by the prosecution why she did not call an ambulance for Lisa when she knew that the child was dangerously ill, she said, "Joel told me he would get Lisa up and I didn't want to show disrespect." ${ }^{50}$ In the UK case $R v$ Emery and Hedman ${ }^{51}$ both parties were charged with assaulting 11 month old Chanel Hedman and with causing suffering to her. She was found to have 22 injuries, including 11 broken ribs. Neither was charged with her murder or manslaughter because the prosecution

\footnotetext{
${ }^{47}$ Home Office Circular 9/2005 The Domestic Violence and Victims Act 2004:The new Offence of causing the death of a child or vulnerable adult, 04/03/2005, Home Office para 18-24.

${ }^{48}$ The trial was held in 1989 and a video documentary made of the trial Inside Story On Trial transmitted by BBC1 June 7, 1989, BBC Programme Number: LDFX410K.

${ }^{49}$ The People of the State of New York, Respondent, $v$ Joel Steinberg, Also Known as Joel Barnet Steinberg, Appellant No. 100 Court of Appeal of New York, 79 N.Y.2d 673; 595 N.E.2d 845; 584 N.Y.S.2d 770; 1992 N.Y. Lexis 1590.

${ }^{50}$ People $v$ Steinberg trial documentary see note 48.

${ }^{51}$ (Unreported) November 3, 1992.
} 


\section{THE DENNING LAW JOURNAL}

were unable to determine which of them inflicted the fatal injury. The court heard that Sally Emery, suffered from post-traumatic stress syndrome following repeated assaults from Hedman, and that she was in such fear that she was incapable of getting appropriate help and assistance for the child. ${ }^{52}$

Both Hedda Nussbaum and Sally Emery were unable to take "reasonable steps" to prevent the abuse of the children in their care. Such cases illustrate the problem under the DVCVA that may present the defence in establishing that a co-defendant could not take reasonable steps to protect. More recently the Ullah case ${ }^{53}$ illustrates the predicament of a mother's inability to protect her child where a partner is violent. Sitab Ullah, was convicted of murder, he believed that his baby daughter was possessed, and battered and abused her. The child's mother, Salma Begum, pleaded guilty to child neglect. She gave evidence from behind a screen, (following a special measures direction) and told the court how Ullah had said that Samira was not his child and was possessed by spirits. "He didn't want me to feed her too much. He complained she was becoming greedy because he thought the thing inside her wanted to be fed all the time." ${ }^{54}$ She had on two occasions been re-housed because of the domestic violence she suffered. Counsel, described her as a woman who showed the classic signs of being a battered wife unable to take reasonable steps to protect her child. The court sentenced her to 15 months imprisonment for child neglect. ${ }^{55}$ More recently Sandra Mujuru, was charged with failing to protect her daughter (section 5 DVCVA) her partner was convicted of murdering the child. Sandra Mujuru was described by the judge as a "decent young woman who was in a vulnerable position" ${ }^{56}$ and given a non-custodial sentence.

A woman's fear of the perpetrator may also prevent her from speaking about what has occurred. Prosecuting authorities and the courts should be open to this reality and it is here that an expert witness ${ }^{57}$ addressing the court on the effects of violence on the mother or carer might be of assistance to the court.

\footnotetext{
${ }^{52}$ Cited in $R v$ Hurst [1995] 1 Cr App Rep 82.

${ }^{53}$ The Guardian, December 23, 2005.

${ }^{54}$ The Youth Justice and Criminal Evidence Act 1999, part II, chapter I (ss. 16 to 33) "fear or distress they are likely to suffer when giving evidence" (section 17).

${ }^{55}$ The Guardian, December 23, 2005.

${ }^{56}$ Express, May 6, 2006.

${ }^{57}$ In this context it is worth noting the public condemnation of mothers of child victims. In the US case against Gabriela Hernandez,' a Ventura County judge sentenced her to 11 years and told the 23-year-old he could not understand why she failed to stop her husband from beating her two year old daughter to death. The 2nd Appellate District Court overturned the 1998 conviction, saying that the Ventura County Superior Court judge in that trial should have allowed expert testimony on her being a battered wife. (Los Angeles Times, April 24, 2001).
} 


\section{THE DENNING LAW JOURNAL}

The Law Commission, in its Report, emphasised that silence of itself should not inculpate in such circumstances, and said:

"...where the evidence was such that the defendant was so close to the events that he or she must either have been the perpetrator, or been complicit in it, or be able, even if only by exculpatory evidence, to cast light on which other person was responsible for the child's death or injury, then the court may well conclude that the circumstances so called for an explanation from him or her, as a person with the statutory responsibility, that it would be proper to permit the jury to draw an adverse inference from the defendant's silence. In such a case the 'eloquent silence' of the defendant might be said to be the 'decisive' element in a decision to convict but it would not mean that the defendant was convicted 'solely or mainly' on an inference from silence any more than the 'decisive' straw is the 'sole or main' cause of the camel's broken back." 58

Whilst section 6 of the DVCVA allows adverse inferences to be drawn from a failure to give evidence or a refusal to answer a question, it will be a matter for the judge whether a direction is appropriate:

"6(1) Subsections (2) to (4) apply where a person ('the defendant') is charged in the same proceedings with an offence of murder or manslaughter and with an offence under section 5 in respect of the same death ('the section 5 offence').(2) Where by virtue of section 35(3) of the Criminal Justice and Public Order Act 1994 (c. 33) a court or jury is permitted, in relation to the section 5 offence, to draw such inferences as appear proper from the defendant's failure to give evidence or refusal to answer a question, the court or jury may also draw such inferences in determining whether he is guilty-

(a) of murder or manslaughter, or

(b) of any other offence of which he could lawfully be convicted on the charge of murder or manslaughter, even if there would otherwise be no case for him to answer in relation to that offence.

(3) The charge of murder or manslaughter is not to be dismissed under paragraph 2 of Schedule 3 to the Crime and Disorder Act 1998 (c. 37) (unless the section 5 offence is

${ }^{58}$ See note 41 above, paras 6.86 and 6.87 of the Law Commission Report. 


\section{THE DENNING LAW JOURNAL}

dismissed). (4) At the defendant's trial the question whether there is a case for the defendant to answer on the charge of murder or manslaughter is not to be considered before the close of all the evidence (or, if at some earlier time he ceases to be charged with the section 5 offence, before that earlier time).”

The predicament for the battered woman in such circumstances is expressed by Bessant who asserts: "The result of section 5 and section 6 together is to present an unenviable choice to the defendant: fail to give evidence, thereby risk adverse inferences and a prosecution on the section 5 offence, or risk giving evidence which may bolster a weak prosecution case for murder or manslaughter" (sic). ${ }^{59}$ The position with regard to the drawing of adverse inference at trial is governed by $R \vee$ Cowan $^{60}$ where the Court of Appeal considered the effect of the section together with the specimen direction published by the Judicial Studies Board (JSB). The House of Lords in $R v$ Becouarn ${ }^{61}$ upheld Cowan as good law. There is a further problem with section 5 which is that it is not necessary for the jury to reveal on what basis they are convicting either of the co-defendants. So, a jury may return a guilty verdict on co-defendant $A$ and co-defendant $B$, where they believe that defendant A caused the death and that defendant $B$ allowed the death. A judge in sentencing faced with this scenario could sentence defendant $B$ on the basis that $\mathrm{s} /$ he caused the killing of the child when in fact the jury did not believe this to be the case. To avoid this an application for a special verdict to ascertain the basis of the jury's verdict could be made. It would be essential in my view that such an application is made. ${ }^{62}$ (This section will require amendment to severe "causing" from "allowing" leaving "allowing" as an alternate charge). With regard to sentencing, the maximum penalty of 14 years or less for this offence ${ }^{63}$ (which is less than the maximum for manslaughter and murder) ${ }^{64}$ is designed to

\footnotetext{
${ }^{59}$ Bessant note 19 above p.5.

${ }^{60}$ [1995] 4 All ER 939.

61 [2005] UKHL 55: [2005] 4 All ER 673.
}

${ }^{62}$ For the importance of the use of special verdicts see Malhi [1994] Crim LR 755. See also the need where appropriate for a Newton hearing. A Newton hearing is where the $\mathrm{D}$ admits some facts of case but disputes others, or admits facts of case but disputes the charge. For example, a Newton hearing may be requested by the defence where D admits stealing a mobile phone from a person using it in the street and admits the facts (admitting to theft) but does not admit to a charge of robbery (which requires the additional element of fear or force). The Newton hearing is considered a trial where the judge considers submissions before proceeding to sentence, see $R v$ Newton [1983] Crim LR 198.

${ }^{63}$ DVCVA 2004 section 5 ss7.

${ }^{64}$ See Criminal Justice Act 2003, chapter seven, section 269. 


\section{THE DENNING LAW JOURNAL}

induce one party to give evidence against the other. If both parties can be sentenced to up to a maximum of 14 years it may not be much of an inducement.

\section{RIGHTS - WHOSE RIGHTS?}

Finally, the trouble with domestic violence assaults perpetrated against adults is not only a question of substantive law but remains one of effective prosecution. Getting victims to court remains an intransigent problem largely because women are afraid to give evidence against perpetrators. The CJA 2003, section 116 provides for putting before a court a victim's statement in place of her oral testimony, as one of the exceptions to hearsay, if: "...the court is satisfied that the case for excluding the statement, taking account of the danger that to admit it would result in undue waste of time, substantially outweighs the case for admitting it, taking account of the value of the evidence" (section 126 (1)(b)).

Applications by the prosecution to admit witness statements made to police are subject to defence objections that admission of such documentary evidence abrogates the fairness of the trial under art 6 (3)(d) of the European Convention of Human Rights (ECHR) since the witnesses evidence cannot be tested or the witness cross examined as to her evidence. There is very little jurisprudence on the specific circumstances prevailing in domestic violence cases on this point. However, the Strasbourg jurisprudence has established in several cases that the admission of a witness statement will not automatically be held to have contravened art 6 even if it is the sole evidence against the defendant. ${ }^{65}$ In any event, the question of whether the admission of a statement renders a trial unfair is a matter for national courts. ${ }^{66}$ This question was considered in the specific context of domestic violence in $R$ (on the application of Robinson) $v$ Sutton Coldfield Magistrates' Court ${ }^{67}$ where an application for judicial review was dismissed on both grounds of the application. The first ground was that evidence of bad character had wrongly been admitted and the second ground that the defendant had been deprived of the opportunity to cross examine the witness as her statement was accepted in place of her attending court and giving evidence because she said she was in fear.

More recently the Sentencing Guidelines Council $^{68}$ has issued a Consultation Paper on Domestic Violence which proposes that the following

\footnotetext{
${ }^{65} R v$ Campbell, [2005] EWCA Crim 2078.

${ }^{66} R v$ Sellick $v$ Sellick [2005] EWCA Crim 651, [2005] 1 WLR 3257.

${ }^{67}$ Queen's Bench Division (Divisional Court) [2006] EWHC 307 (Admin), CO/4926/2005, (Transcript: Smith Bernal Wordwave).

${ }^{68}$ Sentencing Guidelines Council Consultation Paper Overarching Principles: Domestic Violence.
} 


\section{THE DENNING LAW JOURNAL}

aggravating and mitigating factors should be taken into consideration by sentencers. The aggravating factors include; the presence of children, the use of violence in contact arrangements made in respect of children, where the victim is particularly vulnerable, where there is a history of domestic violence, a history of breaching court orders and where the victim is forced to leave the home. Mitigating factors, they suggest, include the use of violence as an isolated incident, and good character. Although the SGC acknowledge that in such cases the offender may have two characters and good character outside the home should only be of minor relevance. The SGC also warn that sentencers should be wary of attempts by the defendant to suggest that the violence was provoked. The SGC also suggests that the wishes of the victim should be treated with caution since there is a risk that a plea for mercy made by victims might be induced by the offender. As a general proviso the proposals stress that serious violence will warrant a custodial sentence. They also propose that where the offence has passed the custody threshold and a short custodial sentence is anticipated certain exceptions to custody (in these cases) might be indicated where there is genuine remorse, where there is a real prospect of rehabilitation and reform, and where preservation of the relationship is intended. These are, as the proposals state, exceptions and the circumstances would need to be exceptional. The importance of these proposals in their effort to introduce some rationality into the sentencing decision has been misrepresented by the media which has failed to consider the proposals in context. It has been widely reported that the proposals are suggesting that a defendant who says he is "sorry" will evade a custodial sentence. ${ }^{69}$ It is important that the proposals in their entirety receive proper and full consideration in the effort to address the problem of domestic violence.

\footnotetext{
${ }^{69}$ Press reports were somewhat distorted suggesting that the guidelines were advocating non-custodial sentences for offenders who said "sorry." The Times April 12, 2006.
} 